\title{
RELEVANSI NILAI REVALUASI ASET TETAP DENGAN TINGKAT UTANG SEBAGAI VARIABEL MODERASI
}

\author{
Fransisca Ayudya Aryani \\ Agung Juliarto \\ Universitas Diponegoro
}

\begin{abstract}
This study aims to analyze the value relevance of fixed asset revaluation and whether debt levels moderate value relevance of fixed asset revaluation. Signaling theory states that the company revalues its assets with the aim to provide credible signals about favorable future prospects; whereas debt contracting theory suggests that firms with high debt levels have opportunistic motives in doing the revaluation of fixed. This study uses 54 data of nonfinancial companies listed on the Indonesian Stock Exchange and have revalued its fixed assets in the period 2012-2015. The results shows that the revaluation of fixed asset has a value relevance, and leverage moderates this value relevance. Companies are trying to show the fair value of assets and an overview of the actual company's financial condition by revaluing their assets. However, when the company revalued its assets and has a fairly high leverage, investor respons negatively on revaluation conducted. Investors perceive that it is an opportunistic motives of managers to avoid the costs arising from the loan agreement.
\end{abstract}

Keywords: Revaluation of Fixed Assets, Leverage, Value Relevance, Opportunistic Motives

\section{Pendahuluan}

Laporan keuangan merupakan salah satu bentuk pertanggungjawaban manajer kepada para pemangku kepentingan. Laporan keuangan mampu menunjukkan kondisi dan kinerja perusahaan dalam periode waktu tertentu, serta digunakan oleh beberapa pihak untuk membuat keputusan ekonomi. Selain itu, laporan keuangan juga mampu menunjukkan posisi keuangan, perubahan ekuitas, jalannya operasional perusahaan, dan kekayaan yang dimiliki perusahaan. Pada dasarnya perusahaan selalu berusaha untuk menyajikan laporan keuangan yang baik, yaitu mencakup kondisi yang relevan, dapat diandalkan dan tidak menyesatkan. Penilaian kembali atau revaluasi adalah cara yang dapat digunakan perusahaan untuk menyajikan informasi yang relevan mengenai kondisi keuangan perusahaan.

Pada tanggal 22 Oktober 2015, pemerintah mengeluarkan paket kebijakan ekonomi jilid $\mathrm{V}$ yang salah satu isinya mencakup kegiatan revaluasi aset tetap. Kebijakan ini dibuat karena masih banyaknya perusahaan yang belum melakukan revaluasi aset. Selain itu, revaluasi ini dipandang perlu untuk meningkatkan kinerja perusahaan (kemenkopmk.go.id, 2015). Brown et al. (1992) memandang bahwa revaluasi aset 
akan mengakibatkan rasio utang terhadap aset maupun ekuitas menjadi semakin baik. Djohan Pinnarwan, ketua Dewan Standar Akuntansi Keuangan Ikatan Akuntansi Indonesia (DSAK IAI) menyebutkan bahwa revaluasi ini ditujukan untuk memperbaiki neraca perusahaan. Perusahaan akan melakukan revaluasi ke atas (upward revaluation) dalam upaya untuk menyajikan kondisi keuangan yang baik, mampu menarik investor, serta memperkuat peluang investasi (MissonierPiera, 2007).

Masalah lain yang mendorong adanya revaluasi adalah kurangnya investasi. Permasalahan ini dapat diperburuk karena adanya perjanjian yang melibatkan angkaangka akuntansi, misalnya perjanjian dengan menetapkan batas pinjaman berdasarkan persentase total aset berwujud. Dengan perjanjian semacam ini, apabila aset perusahaan yang dijadikan jaminan utang dinilai kecil, maka dana yang tersedia dari pihak eksternal (misalnya, Bank) akan berkurang. Ketika perusahaan berusaha melakukan negosiasi kembali atas perjanjian utang yang telah disepakati untuk mendapatkan dana pinjaman yang lebih banyak, hal ini akan memakan biaya dan waktu yang tidak sedikit (Courtenay dan Cahan, 2004). Whittred dan Chan (1992) berpendapat bahwa revaluasi aset adalah salah satu cara yang murah untuk meningkatkan kapasitas pinjaman tanpa melakukan renegosiasi kontrak. Dengan melakukan revaluasi aset, perusahaan dapat melonggarkan batasan utang karena nilai aset akan meningkat dan leverage menurun. Atas dasar inilah, peneliti menduga bahwa leverage memiliki dampak terhadap keputusan manajer dalam melakukan revaluasi.

Penelitian yang dilakukan Easton et al. (1993) menemukan bukti bahwa selisih revaluasi aset tetap memiliki hubungan yang lemah dengan return. Mereka juga menguji apakah terdapat perbedaan relevansi nilai revaluasi aset pada perusahaan yang memiliki tingkat utang tinggi maupun rendah. Dengan menggunakan model berbasis harga, Easton et al. (1993) menemukan hubungan antara saldo cadangan revaluasi aset tetap dan harga saham hanya pada perusahaan yang memiliki tingkat utang tinggi. Easton et al. memandang bahwa revaluasi aset tetap dilakukan untuk memberikan sinyal kepada investor (efisiensi kontrak). Di sisi lain, Aboody et al. (1999) menemukan bukti bahwa peningkatan saldo cadangan revaluasi berhubungan positif dan signifikan terhadap return saham maupun return tahunan (harga). Mereka juga meneliti apakah hubungan ini dipengaruhi oleh jumlah utang perusahaan. Dengan menggunakan harga saham, mereka menemukan hubungan negatif dan signifikan. Aboody et al. (1999) 
menunjukkan bahwa pasar mengakui adanya motif oportunistik manajer dalam melakukan revaluasi.

Brown et al. (1992) mengajukan dua hipotesis dalam menjelaskan motif perusahaan dalam melakukan revaluasi aset tetap. Pertama, perusahaan dengan tingkat utang yang lebih tinggi memiliki motif oportunistik dalam merevaluasi aset tetap ke atas (upward revaluations) untuk melonggarkan kendala utang.Motif ini memungkinkan perusahaan untuk mendapatkan keuntungan dengan menghindari hukuman atau biaya renegosiasi terkait pelanggaran perjanjian utang (Courtney dan Cahan, 2004). Brown et al. juga menyatakan bahwa perusahaan erusahaan mungkin merevaluasi aset tetap untuk menghindari transfer kekayaan dari entitas untuk pemberi pinjaman, misalnya biaya renegosiasi kontrak. Kedua, perusahaan dengan senjangan keuangan yang rendah, misalnya, cadangan kas dan sekuritas berharga rendah, dapat menggunakan revaluasi untukmengurangi asimetri informasi dan memberikan sinyal bahwa aset perusahaan dinilai kurang (undervalued). Dengan meningkatkan nilai total aset berwujud, manajer dapat memperoleh pinjaman dan meningkatkan senjangan keuangan. Alasan lain dikemukakan oleh Whittred dan Chan
(1992) yang menyatakan bahwa perusahaan mungkin melakukan revaluasi aset tetap untuk meningkatkan kapasitas pinjaman sehingga mereka dapat berinvestasi dengan mudah. Alasan tersebut didasarkan pada hasil penelitian Whittred dan Chan (1992) pada perusahaan di Australia baik yang melakukan revaluasi aset maupun tidak, menunjukkan bahwa kecenderungan untuk merevaluasi aset berhubungan positif dengan perjanjian utang, tingkat rasio leverage, kesempatan investasi perusahaan, dan berhubungan negatif dengan tingkat cadangan kas.

Pentingnya penelitian ini didasarkan pada ketidak konsistenan penelitian terdahulu mengenai ada tidaknya relevansi nilai revaluasi aset tetap. Masih belum jelas apakah motif perusahaan dalam melakukan revaluasi aset bergantung pada tinggi rendahnya jumlah utang perusahaan. Selain itu, perlu dilakukan pengujian mengenai relevansi nilai revaluasi aset tetap khususnya dengan menggunakan data di Indonesia. Hal tersebut berkaitan dengan dikeluarkannya paket kebijakan ekonomi jilid V pada tahun 2015, yang salah satu isinya adalah mendorong perusahaan untuk melakukan revaluasi aset tetap. Dalam penelitian ini, leverage diduga memoderasi hubungan antara revaluasi aset tetap terhadap return saham. Oleh karena itu, 
dapat disimpulkan bahwa rumusan masalah dalam penelitian ini adalah:

a. Apakah revaluasi aset tetap memiliki relevansi nilai?

b. Apakah leverage memoderasi relevansi nilai dari revaluasi aset tetap?

Tujuan yang ingin dicapai dalam penelitian ini adalah untuk memberikan bukti empiris mengenai ada tidaknya relevansi nilai revaluasi aset tetap dan menguji apakah tingkat utang (leverage) memoderasi relevansi nilai tersebut, serta mengetahui motif manajer dalam melakukan revaluasi aset tetap.

\section{Kerangka Teoritis dan Pengembangan}

\section{Hipotesis}

Teori Kontrak Utang (Debt Contracting Theory) dan Teori Sinyal (Signaling Theory) adalah teori yang digunakan untuk menjelaskan apakah tujuan manajer perusahaan dalam melakukan revaluasi aset tetap. Dalam bagian ini juga akan dibahas beberapa konsep mengenai aset tetap, revaluasi aset tetap, relevansi nilai, dan tingkat utang (leverage) yang berkaitan dengan penelitian yang dilakukan.

\section{Teori Kontrak Utang (Debt Contracting}

Theory)

Teori kontrak utang yang dikemukakan oleh Brown et al.(1992) menyebutkan karena revaluasi aset berkaitan dengan angka-angka akuntansi, keputusan manajemen untuk merevaluasi aset menyebabkan perbedaan pada profil keuangan perusahaan. Pada umumnya, revaluasi dapat mengubah rasio utang terhadap aset menjadi lebih baik. Rasio ini biasanya digunakan dalam melakukan perjanjian kontrak utang. Dengan rasio yang semakin baik, perusahaan lebih mungkin untuk mendapatkan keuntungan dalam melakukan renegosiasi kontrak dan penghindaran pelanggaran perjanjian utang. Pelanggaran terhadap utang menyebabkan biaya bagi perusahaan karena investasi yang dilakukan dan pilihan pendanaan akan dibatasi pada jumlah yang tidak optimal. Selain itu, kegagalan utang dapat menimbulkan biaya pembayaran kontrak utang kembali atau biaya renegosiasi kontrak. Karena revaluasi dapat meningkatkan nilai buku aset berwujud, hal ini dapat mengurangi hambatan dalam perjanjian utang. Batasan formal pada leverage yang ditentukan dalam syarat perjanjian utang akan meningkatkan probabilitas manajemen untuk melakukan revaluasi (Brown et al., 1992).

\section{Teori Sinyal (Signaling Theory)}

Teori sinyal digunakan untuk menjelaskan bahwa laporan keuangan dapat dijadikan sebagai alat untuk memberikan sinyal yang positif maupun negatif kepada pemakainya. Lin dan Peasnell (2000) dan 
Barlev et al. (2007) (dalam Choi et al., 2013) berpendapat bahwa dengan menilai kembali aset tetap (Property, plant \& equipments) perusahaan memberikan sinyal yang positif dan kredibel mengenai prospek masa depan yang lebih menguntungkan. Sebaliknya, Gaeremynck dan Veugelers (1999) (dalam Choi et al., 2013) berpendapat bahwa revaluasi akan memberikan sinyal yang negatif mengenai kinerja buruk perusahaan karena adanya kendala utang. Perusahaan juga akan melakukan revaluasi dalam upaya untuk memperbaiki posisi keuangan untuk meningkatkan kapasitas pinjaman atau untuk menghindari pelanggaran perjanjian utang.

Di sisi yang lain, Andison (2015) menganggap pentingnya teori ini didasarkan pada fenomena asimetri informasi antara manajer dan investor. Keadaan ini mendorong manajer untuk segera memberikan sinyal agar investor memiliki pengetahuan dan gambaran yang cukup mengenai perusahaan bersangkutan. Umumnya perusahaan akan senantiasa menempatkan posisinya sebagai perusahaan yang baik untuk menunjukkan kualitas dirinya melalui sinyal-sinyal yang diberikan oleh perusahaan (Bhattacarya dan Amy, 2011; Andison, 2015).

\section{Aset Tetap}

PSAK NO. 16 mendefinisikan aset tetap sebagai aset berwujud yang a) dimiliki untuk digunakan dalam produksi atau penyediaan barang atau jasa, untuk direntalkan kepada pihak lain, atau untuk tujuan administratif, dan b) diharapkan untuk digunakan selama lebih dari satu periode. Aset tetap diakui sebesar biaya perolehan pada saat pengakuan awal, jika dan hanya jika entitas akan memperoleh manfaat ekonomi di masa depan dari aset tersebut dan biaya perolehannya dapat diukur secara andal. Sedangkan untuk pengukuran aset tetap setelah pengakuan, perusahaan dapat memilih untuk menggunakan model biaya atau model revaluasi (IAI, 2011).

Perusahaan dapat memilih model biaya atau model revaluasi sebagai kebijakan akuntansinya dalam melakukan pengukuran aset tetap setelah pengakuan awal. Kebijakan tersebut harus diterapkan terhadap seluruh aset tetap pada kelompok yang sama. Apabila perusahaan mengukur aset tetap dengan menggunakan model biaya, maka pengukuran dilakukan dengan mengurangkan biaya perolehan aset tetap dengan akumulasi penyusutan dan akumulasi rugi penurunan nilai aset. Sedangkan pengukuran dengan menggunakan model revaluasi dilakukan 
dengan mencatat nilai aset tetap sebesar nilai wajar pada tanggal revaluasi dikurangi dengan akumulasi penyusutan dan akumulasi rugi penurunan nilai aset tetap yang terjadi setelah tanggal revaluasi (IAI, 2011).

\section{Revaluasi Aset Tetap}

Revaluasi aset tetap adalah penilaian kembali aset tetap dalam rangka menyediakan informasi nilai wajar dari aset yang dimiliki perusahaan. Revaluasi dilakukan ketika nilai aset dinilai tidak mencerminkan nilai yang sesungguhnya. Perusahaan yang memilih untuk menggunakan model revaluasi harus melakukan penilaian kembali secara teratur dan cukup reguler untuk memastikan jumlah yang tercatat tidak berbeda secara material dari jumlah nilai wajar pada akhir periode pelaporan. Jika nilai aset meningkat setelah revaluasi, maka kenaikan tersebut langsung dikreditkan ke ekuitas pada bagian surplus revaluasi. Kenaikan tersebut juga harus diakui dalam laporan laba rugi hingga sebesar jumlah penurunan nilai aset akibat revaluasi yang diakui sebelumnya. Sedangkan jika jumlah nilai aset setelah dilakukan revaluasi mengalami penurunan, maka penurunan tersebut diakui dalam laporan laba rugi. Penurunan nilai tersebut langsung di debit ke ekuitas pada bagian surplus revaluasi selama penurunan tersebut tidak melebihi saldo kredit surplus untuk aset tersebut (IAI, 2011).

\section{Leverage}

Leverage keuangan adalah penggunaan sumber dana yang digunakan untuk meningkatkan profitabilitas dan menimbulkan beban tetap keuangan, misalnya bunga. Syamsuddin (2002) (dalam Maruli, 2014) menyatakan bahwa rasio leverage adalah kemampuan perusahaan dalam mendayagunakan aset atau dana yang memiliki beban tetap, utuk menambah tingkat pengembalian (return) bagi pemilik perusahaan. Leverage dapat memengaruhi tingkat dan variabilitas pendapatan setelah pajak, dan juga risiko serta tingkat pengembalian keseluruhan. Leverage keuangan juga digunakan dengan tujuan untuk dapat menambah tingkat pengembalian kepada pemegang saham biasa (Horn dan Wachowicz, 2007).

\section{Relevansi Nilai}

Beaver (1968) mendefinisikan relevansi nilai sebagai kemampuan menjelaskan (explanatory power) dari informasi akuntansi yang berkaitan dengan nilai perusahaan. Hal serupa juga dinyatakan oleh $\mathrm{Gu}$ (2007) yang memberi arti sebagai explanatory power informasi akuntansi terhadap return dan harga saham. Terdapat dua model yang biasa digunakan dalam menilai relevansi nilai, yaitu dengan menggunakan model return dan model 
harga. Pengukuran dengan menggunakan model harga menggunakan $\mathrm{R}^{2}$ sebagai pengukur relevansi nilai (Francis dan Schipper, 1999; Simbolon,2010).

Penggunaan $\mathrm{R}^{2}$ didasarkan pada alasan karena $\mathrm{R}^{2}$ adalah pengukur yang baik dalam menjelaskan variabel independen dalam suatu regresi. Di sisi yang berlainan, Brown et al. (1999) (dalam Simbolon, 2010) menemukan adanya masalah scale efect dalam model harga. Brown et al. (1999) mengatasi permasalahan ini dengan menggunakan model return, yaitu $\mathrm{P}_{\mathrm{t}-1}$ sebagai pembagi dalam model tersebut. Sejalan dengan Brown et al. (1999), Barth dan Clinch (1998) juga menyatakan bahwa model return lebih mencerminkan adanya ketepatan waktu. Dengan demikian, revaluasi yang dilakukan sebelum maupun setelah periode sekarang tidak akan memiliki relevansi nilai.

\section{Kerangka Pemikiran}

Dalam penelitian ini, revaluasi aset tetap digunakan sebagai variabel independen yang memengaruhi return saham. Peneliti berfokus pada revaluasi ke atas karena merupakan diskresioner yang baik dari segi waktu dan jumlah (Courtenay dan Cahan, 2004). Dengan demikian, semua revaluasi dianggap secara langsung menambah atau mengurangi ekuitas. Peneliti mengharapkan hasil uji yang positif dan signifikan dalam hubungan antara revaluasi aset tetap dengan return saham. Hal ini menunjukkan adanya relevansi nilai pada revaluasi aset tetap.

Beberapa hal lain yang mendorong perusahaan untuk melakukan revaluasi aset mungkin karena adanya keinginan manajer untuk meningkatkan nilai aset dalam rangka untuk memperbaiki beberapa rasio keuangan, misalnya rasio utang atas ekuitas (Debt to Equity Ratio) dan rasio utang atas aset (Debt to Assets Ratio). Brown et al. (1992) mengasumsikan bahwa perusahaan degan tingkat utang yang tinggi mungkin memiliki motif oportunistik dalam melakukan revaluasi. Motif ini didasari oleh keinginan manajer untuk mendapatkan kelonggaran dalam perjanjian utang, seperti, penghindaran denda dan pembayaran biaya renegosiasi. Whittred dan Chan (1992) berpendapat bahwa revaluasi aset adalah cara yang murah untuk meningkatkan kapasitas pinjaman tanpa harus melakukan renegosiasi kontrak.

Sama seperti asumsi yang dinyatakan oleh Brown et al. (1992), perusahaan mungkin memiliki motif yang berbeda dalam melakukan revaluasi aset. Perusahaan yang memiliki tingkat utang tinggi lebih cenderung untuk melakukan revaluasi sebagai motif oportunistik dalam rangka untuk melonggarkan kendala utang. 
Sedangkan Whittred dan Chan (1992) yang mendukung pandangan bahwa mengasumsikan bahwa bahwa perusahaan perusahaan memiliki motif oportunistik yang memiliki tingkat utang yang tinggi dalam melakukan revaluasi aset, sedangkan melakukan revaluasi sebagai bentuk Easton et al. (1993) membuktikan bahwa efisiensi kontrak, yaitu untuk mengatasi perusahaan memiliki motif untuk masalah kurangnya investasi. Penelitian melakukan efisiensi kontrak utang. Aboody et al. (1999) menemukan bukti

Gambar 1

Kerangka Pemikiran
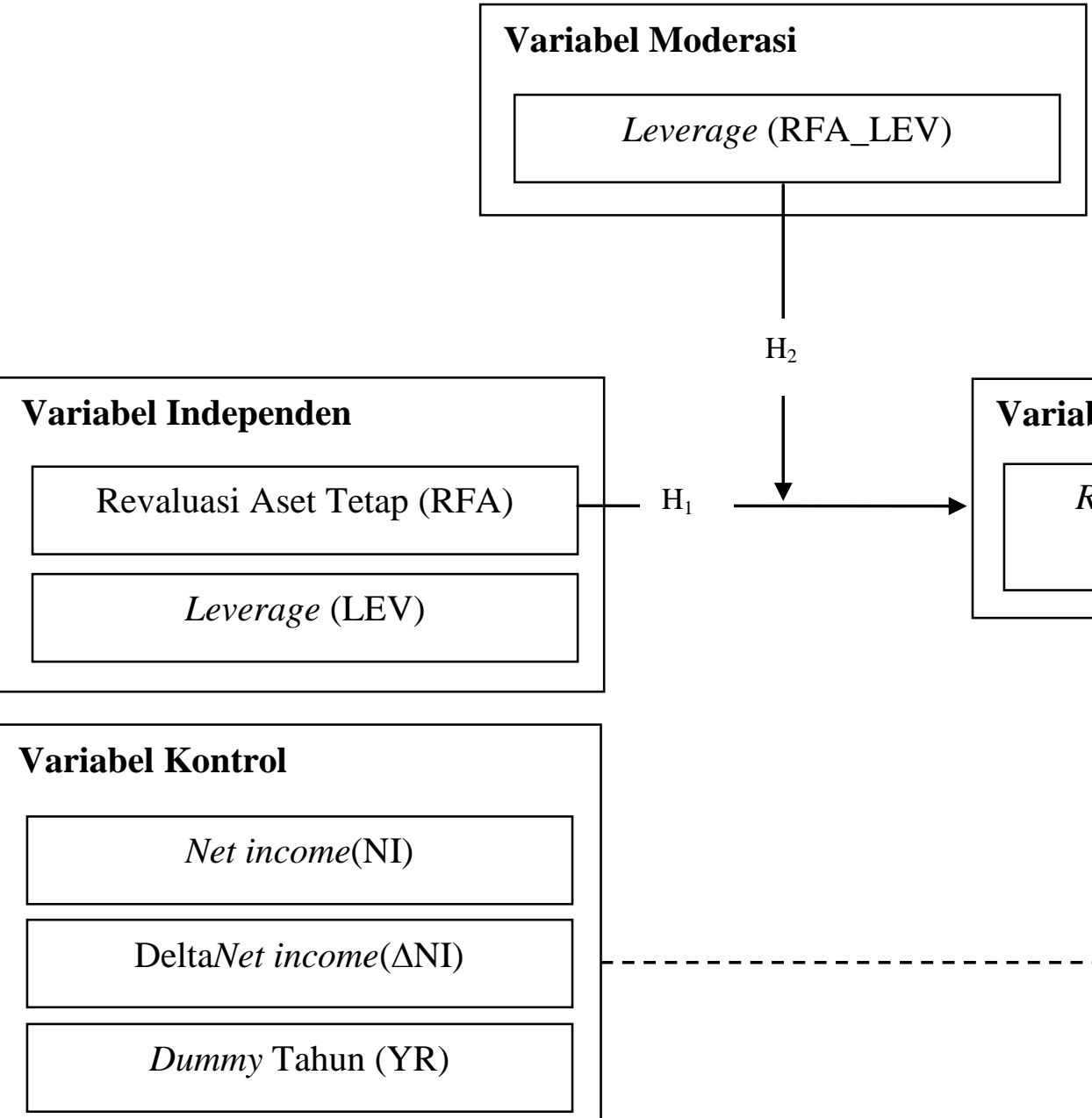

Dalam penelitian ini, leverage diduga memoderasi relevansi nilai revaluasi aset tetap. Penelitian yang dilakukan diharapkan memiliki hasil uji yang signifikan negatif pada perusahaan yang memiliki tingkat

leverage tinggi, artinya bahwa perusahaan dengan rasio leverage yang tinggi akan memiliki return yang lebih rendah. Perusahaan dengan rasio leverage tinggi lebih cenderung bertujuan untuk 
melonggarkan kendala utang sebagai motif oportunistik perusahaan.

Relevansi Nilai Revaluasi Aset Tetap

Cahan et al. (2000) dengan menggunakan model penilaian tingkat harga, membuktikan bahwa revaluasi aset tetap memiliki relevansi nilai dengan laba bersih. Penelitian yang dilakukan Barth dan Clinch (1998) dengan menggunakan model berbasis harga saham, menemukan bahwa revaluasi aset operasional, seperti Property, Plant \& Equipment memiliki relevansi nilai lebih tinggi daripada aset yang tidak berhubungan langsung dengan operasi. Easton et al. (1993) menemukan bahwa selisih revaluasi aset tetap memiliki hubungan yang lemah dengan return dan perubahan laba. Hal ini menunjukkan bahwa selisih revaluasi berkontribusi sangat sedikit terhadap adanya perubahan laba. Di sisi lain, Aboody et al. (1999) menemukan bahwa peningkatan saldo cadangan revaluasi berhubungan signifikan positif terhadap return tahunan. Hasil penelitian Aboody et al. memberikan arti bahwa apabila saldo cadangan revaluasi mengalami peningkatan, maka return tahunan juga akan meningkat.

Dalam perumusan hipotesis pertama penelitian ini, revaluasi aset tetap diduga memiliki pengaruh positif dan memiliki nilai yang signifikan terhadap return saham. Hubungan ini menunjukkan bahwa revaluasi aset tetap memiliki relevansi nilai. Dengan demikian, perusahaan berusaha untuk menampilkan posisi keuangan yang baik untuk memberikan sinyal kepada investor mengenai prospek masa depan yang lebih menguntungkan. Berdasarkan uraian di atas, rumusan hipotesis penelitian yang pertama adalah:

H1. Revaluasi Aset Tetap Memiliki Relevansi Nilai.

\section{Dampak Tingkat Utang Terhadap}

\section{Relevansi Nilai Revaluasi Aset tetap}

Revaluasi aset tetap dilakukan untuk mengatasi masalah kurangnya investasi. Whittred dan Chan (1992) memandang bahwa revaluasi merupakan cara yang murah untuk meningkatkan kapasitas pinjaman tanpa melakukan renegosiasi kontrak. Dengan melakukan revaluasi, perusahaan akan mendapatkan nilai debt to equity ratio (DER) yang lebih rendah karena nilai aset akan meningkat. Brown et al. (1992) menunjukkan dua hipotesis yang berbeda, pertama, perusahaan berusaha untuk menghindari transfer kekayaan kepada pemberi pinjaman, misalnya biaya utang yang tinggi, dengan merevaluasi aset tetapnya. Kedua, perusahaan melakukan revaluasi aset mungkin disebabkan oleh keinginan untuk mengurangi asimetri 
informasi antara pihak internal dan eksternal perusahaan.

Perusahaan mungkin memiliki motif yang berbeda dalam melakukan revaluasi aset. Misalnya, perusahaan dengan leverage yang tinggi mungkin memiliki motif yang berbeda dengan perusahaan dengan leverage yang rendah. Sama dengan hipotesis Aboody et al. (1999) dan Brown et al. (1992) bahwa perusahaan yang memiliki tingkat utang tinggi mungkin memiliki motif oportunistik untuk menghilangkan hambatan utang dengan melakukan revaluasi. Di sisi lain, Whittred dan Chan (1992) dan Easton et al. (1993) memandang bahwa perusahaan melakukan revaluasi aset tetap sebagai bentuk efisiensi kontrak dan memperluas kapasitas pinjaman.

Penelitian ini menguji apakah tingkat utang perusahaan mempengaruhi relevansi nilai revaluasi aset tetap. Moderasi dari variabel leverage, menunjukkan adanya pengaruh tingkat utang terhadap relevansi nilai revaluasi aset tetap. Pengaruh negatif dan signifikan menunjukkan bahwa perusahaan didorong oleh motif oportunistik dalam melakukan revaluasi aset tetap. Kondisi ini mencerminkan bahwa perusahaan berupaya untuk menghindari pelanggaran utang dengan meningkatkan nilai aset melalui revaluasi. Di sisi lain, hasil yang positif dan signifikan menunjukkan bahwa perusahaan didorong oleh motif untuk menghindari adanya asimetri informasi antara pihak internal dan eksternal perusahaan. Hipotesis kedua dalam penelitian ini adalah:

H2. Leverage Memoderasi Relevansi Nilai Revaluasi Aset Tetap.

\section{METODE PENELITIAN}

\section{Variabel Penelitian}

Penelitian ini menguji relevansi nilai revaluasi aset tetap dan moderasi tingkat utang dalam relevansi tersebut. Variabel dependen yang digunakan dalam penelitian ini adalah return saham. Variabel independen dalam penelitian ini adalah nilai revaluasi aset tetap dan moderasi leverage terhadap nilai revaluasi aset tetap.

Variabel dependen return (RET) diukur dengan menggunakan raw return perusahaan 3 bulan setelah berakhirnya periode akuntansi. Raw return dapat dihitung dengan harga saham pada perusahaan $i$ periode $t$ ditambah dengan dividen perusahaan $i$ periode $t$ dikurangkan dengan harga saham perusahaan $i$ periode $t$ 1 dibagi dengan harga saham perusahaan $i$ periode $t-1$ (Aboody et al., 1999); Courtenay dan Cahan, 2004). Return saham digunakan sebagai variabel dependen, sedangkan variabel independennya adalah revaluasi aset tetap. Dalam penelitian ini peneliti menguji dampak tingkat utang untuk melihat apakah tingkat utang 
mempengaruhi relevansi nilai pada revaluasi aset tetap. Peneliti menggunakan model berbasis return untuk menguji relevansi nilai revaluasi aset tetap. Hal ini mengacu pada pernyataan Barth dan Clinch (1998) bahwa model berbasis return lebih mempertimbangkan masalah ketepatan waktu (timeliness) dibandingkan model berbasis harga. Permasalahan waktu ini dianggap penting. Bernard (1993) (dalam Courtenay dan Cahan, 2004) menanggapi penelitian yang dilakukan Easton et al.(1993) bahwa motif oportunis mungkin mempengaruhi waktu dilakukannya revaluasi. $\mathrm{RET}_{\mathrm{t}}$ adalah raw return pada tiga bulan setelah berakhirnya tahun fiskal perusahaan pada periode $\mathrm{t}$.

Keterangan :

RET $_{\mathrm{t}} \quad$ : Raw return 3 bulan setelah tahun fiskal periode $t$

P : Harga saham

DIV : Dividen kas

Variabel independen revaluasi aset tetap (RFA) diukur melalui selisih antara nilai aset setelah revaluasi $\left(\mathrm{FA}_{1}\right)$ dikurangi dengan nilai aset sebelum revaluasi $\left(\mathrm{FA}_{0}\right)$ atau kenaikan revaluasi aset tetap dibagi dengan market value of equity (MVE) awal tahun untuk mengurangi kesenjangan nilai antar variabel (Courtenay dan Cahan, 2004).

$$
\mathrm{RFA}=\left(\mathrm{FA}_{1}-\mathrm{FA}_{0}\right) / \mathrm{MVE}
$$

Leverage biasa digunakan oleh kreditur maupun investor untuk mengetahui posisi keuangan perusahaan. Dengan rasio ini, kreditur maupun investor akan mempertimbangkan keputusan kredit dan investasi kepada perusahaan tersebut. Rasio leverage yang rendah menunjukkan bahwa perusahaan memiliki posisi keuangan yang baik karena perusahaan mampu menutup seluruh utangnya baik jangka pendek maupun panjang saat perusahaan tersebut dilikuidasi. Dalam penelitian ini, rasio leverage (LEV) dihitung dengan membandingkan total liabilitas dengan total ekuitas (Courteney dan Cahan, 2004).

Debt to Equity Ratio $=\frac{\text { Total Liabilitas }}{\text { Total Ekuitas }}$ Variabel moderasi leverage (RFA_LEV) dihitung dengan mengalikan nilai variabel revaluasi aset tetap (RFA) dan leverage (LEV), kemudian dibagi dengan market value of equity (MVE) pada awal tahun t. leverage (LEV) dihitung dengan membandingkan total liabilitas dengan total ekuitas (Courteney dan Cahan, 2004).

\section{RFA_LEV $=($ RFA $x$ LEV $) /$ MVE}

Variabel net income, delta net income, dan dummy tahun digunakan sebagai variabel kontrol. Terdapat tiga dummy untuk mengendalikan fluktuasi return sepanjang tahun dengan 
menggunakan null set tahun 2015 sebagai pembanding (exclude). Kedua variabel kontrol, net income dan delta net income. Variabel revaluasi aset tetap (RFA), moderasi leverage (RFA_LEV), net income $(\mathrm{NI})$, dan delta net income $(\Delta \mathrm{NI})$ dibagi dengan market value of equity awal tahun untuk mengurangi kesenjangan nilai antar variabel (Courtenay dan Cahan, 2004).

\section{Populasi dan Sampel}

Populasi yang digunakan dalam penelitian ini adalah semua perusahaan non keuangan, yang terdaftar di Bursa Efek Indonesia (IDX) dalam periode tahun 20112015. Pengambilan sampel perusahaan menggunakan purposive sampling dengan kriteria sebagai berikut: menerbitkan laporan tahunan dan laporan keuangan yang telah diaudit selama periode 20112015; perusahaan melakukan revaluasi aset tetap dalam periode pengamatan; perusahaan memiliki data lengkap berupa selisih nilai revaluasi aset tetap, net income, total liabilitas, harga saham penutupan 3 bulan setelah berakhirnya periode fiskal, dan nilai total ekuitas; dan seluruh data tersebut harus disajikan dalam mata uang rupiah.

\section{Metode Analisis}

Pengujian hipotesis dilakukan menggunakan analisis regresi Ordinary Least Square (OLS) dengan model regresi sebagai berikut:
$\mathrm{RET}_{i t}=\beta_{0}+\beta_{l} \mathrm{RFA}_{i t}+$ $\beta_{2} \mathrm{LEV}_{i t}+\beta_{3} \mathrm{RFA}_{-} \mathrm{LEV}_{i t}+\beta_{4} \mathrm{NI}_{i t}+\beta_{5} \Delta \mathrm{NI}_{i t}+$ $\Sigma \beta_{Y} \mathrm{YR} Y_{i t}+\varepsilon_{i t}$

Keterangan:

RET $_{i t} \quad$ raw return 3 bulan setelah periode fiskal tahun $\mathrm{t}$

$\beta \quad$ : konstanta

RFA : selisih revaluasi aset tetap

LEV : leverage/tingkat utang

RFA_LEV : moderasi leverage

NI : net income

$\Delta \mathrm{NI} \quad$ : deltanet income

YR : dummy tahun

\section{HASIL DAN DISKUSI}

\section{Gambaran Sampel Penelitian}

Tabel 1 menjelaskan gambaran data secara rinci mengenai jumlah sampel yang digunakan dalam penelitian ini. Sebanyak 36 perusahaan non keuangan yang melakukan revaluasi dengan jumlah 54 pengamatan dalam periode tahun 20112015 dijadikan sampel dalam penelitian.

Berdasarkan Tabel 1, dapat disimpulkan bahwa tidak semua perusahaan melakukan revaluasi secara terus-menerus dalam periode pengamatan. Hal ini menyebabkan perbedaan jumlah kasus revaluasi setiap tahunnya. Kasus revaluasi tertinggi terjadi pada tahun 2015. Hal ini disebabkan karena dikeluarkannya paket kebijakan ekonomi jilid V yang mendorong perusahaan untuk melakukan revaluasi aset tetap. 
Tabel 1

Jumlah Sampel Penelitian

\begin{tabular}{clccccc}
\hline No. & \multicolumn{1}{c}{ Kriteria } & $\mathbf{2 0 1 1}$ & $\mathbf{2 0 1 2}$ & $\mathbf{2 0 1 3}$ & $\mathbf{2 0 1 4}$ & $\mathbf{2 0 1 5}$ \\
\hline 1 & $\begin{array}{l}\text { Perusahaan yang melakukan } \\
\text { revaluasi aset tetap dalam periode }\end{array}$ & 2 & 6 & 9 & 11 & 40 \\
& $\begin{array}{l}\text { 2011-2015 } \\
2\end{array}$ & & & & & \\
$\begin{array}{l}\text { Perusahaan yang menggunakan } \\
\text { mata uang asing }\end{array}$ & & & & & $(5)$ \\
3 & $\begin{array}{l}\text { Perusahaan yang tidak menyajikan } \\
\text { data lengkap }\end{array}$ & & $(2)$ & & $(3)$ & $(4)$ \\
\cline { 2 - 7 } 4 & Jumlah total data setiap tahun & 2 & 4 & 9 & 8 & 31 \\
\hline Jumlah pengamatan & & & $\mathbf{5 4}$ & & \\
\hline
\end{tabular}

Sumber: Data Sekunder, 2017

Data utama yang digunakan dalam penelitian ini adalah tahun 2011-2015, kecuali untuk data harga saham dan selisih laba bersih (deltanet income). Data harga saham menggunakan data tahun 2016 untuk menghitung relevansi nilai tahun 2015, sedangkan selisih laba bersih menggunakan data tahun 2010 untuk menghitung selisih laba. Terdapat 9 perusahaan sampel yang tidak digunakan dalam penelitian ini karena tidak memiliki data lengkap yang dibutuhkan dalam mengukur variabelvariabel penelitian. Hal ini disebabkan terutama karena perusahaan baru menawarkan saham perdananya dalam periode pengamatan.

\section{Statistik Deskriptif}

Statistik deskriptif dalam penelitian ini bertujuan untuk memberikan gambaran data penelitian berdasarkan nilai minimum, maksimum, rata-rata (mean), dan nilai deviasi standar dari masing-masing variabel yang bersangkutan. Distribusi statistik deskriptif untuk setiap variabel penelitian disajikan dalam Tabel 2.

Tabel 2

Statistik Deskriptif

\begin{tabular}{lccccc}
\hline & $N$ & Minimum & Maximum & Mean* & $\begin{array}{c}\text { Std. } \\
\text { Deviation* }\end{array}$ \\
\hline RET & 54 & $-1,000$ & 1,577 & $-0,013$ & 0,473 \\
RFA & 54 & 0,000 & 3,199 & 0,463 & 0,646 \\
LEV & 54 & 0,083 & 11,254 & 1,999 & 2,118 \\
RFA_LEV & 54 & 0,000 & 19,698 & 1,206 & 3,033 \\
NI & 54 & $-1,976$ & 0,825 & $-0,039$ & 0,386 \\
$\Delta$ NI & 54 & $-2,903$ & 1,074 & $-0,118$ & 0,520 \\
\hline
\end{tabular}

*dibulatkan ke tiga angka desimal terdekat

Sumber: Data sekunder yang telah diolah, 2017 
Tabel 2 menunjukkan jumlah pengamatan $(\mathrm{N})$ sebanyak 54 sampel. Hasil output SPSS memberikan gambaran bahwa terdapat tiga variabel dengan nilai rata-rata negatif, yaitu variabel return, net income, dan deltanet income $(\Delta \mathrm{NI})$ dan terdapat tiga variabel dengan nilai rata-rata positif.

Berdasarkan Tabel 2, Return (RET) yang diukur dengan menggunakan rumus $\left(\mathrm{P}_{t}+\operatorname{Div}-\mathrm{P}_{t-1}\right) / \mathrm{P}_{t-1}$ menunjukkan nilai rata-rata negatif sebesar $-0,013$. Hal ini berarti bahwa dalam satu periode laporan keuangan, perusahaan rata-rata memiliki return saham negatif sebesar 0,013 . Nilai deviasi standar lebih besar dibandingkan nilai rata-ratanya, yaitu sebesar 0,473 yang menunjukkan sebaran variabel data yang lebih luas atau memiliki kesenjangan yang cukup besar antara nilai return tertinggi dan terendah. Nilai return saham terkecil sebesar -1,000, sedangkan nilai return saham terbesar sebesar 1,577.

Nilai revaluasi aset tetap (RFA) diukur dari selisih nilai aset tetap setelah revaluasi dengan aset tetap sebelum revaluasi dibagi dengan market value of equity (MVE). Nilai rata-rata RFA sebesar 0,463 , nilai ini bergantung pada besarnya market value of equity. Apabila nilai revaluasi aset tetap tinggi dan nilai pembaginya (market value of equity) kecil, makan nilai variabel revaluasi aset tetap (RFA) juga akan tinggi. Sebaliknya, apabila nilai pembaginya tinggi, maka nilai variabel revaluasi aset tetap (RFA) akan semakin kecil. Nilai deviasi standar dalam variabel RFA sebesar 0,646 menunjukkan sebaran data yang cukup besar, yaitu sebesar. Hal ini ditunjukkan dengan nilai tertinggi RFA sebesar 3,199, sedangkan nilai terendah RFA adalah sebesar 0,000 $(0,000229)$.

Leverage (LEV) yang diukur dengan membagi nilai total liabilitas dengan total ekuitas memiliki nilai rata-rata sebesar 1,999, hal ini menunjukkan bahwa rata-rata perusahaan memiliki nilai leverage yang cukup tinggi, yaitu sebesar 1,999. Nilai deviasi standar variabel leverage sebesar 2,118 menunjukkan bahwa sebaran data dalam penelitian memiliki kesenjangan nilai yang kecil. Nilai tertinggi sebesar 11,254 dan nilai terendah sebesar 0,083.

Variabel leverage yang memoderasi revaluasi aset tetap (RFA_LEV) diukur dengan mengalikan nilai revaluasi aset tetap dengan nilai leverage kemudian dibagi dengan market value of equity (MVE). Nilai rata-rata variabel RFA_LEV sebesar 1,206. Ketika nilai variabel revaluasi aset tetap (RFA) tinggi dan nilai leverage (LEV) tinggi, maka nilai variabel moderasi leverage (RFA_LEV) juga akan tinggi, dan sebaliknya. Jika nilai revaluasi aset tetap (RFA) rendah namun nilai leverage tinggi atau sebaliknya, maka nilainya akan tinggi. Nilai deviasi standar sebesar 3,033, jauh di atas nilai rata-rata 
menunjukkan bahwa sebaran data hal ini menunjukkan bahwa setiap mengalami kesenjangan yang cukup besar. perusahaan mengalami penurunan laba Hal ini juga ditunjukkan melalui nilai rata-rata sebesar 0,118 dari total kapitalisasi tertinggi sebesar 19,698 yang terpaut jauh dengan nilai terendahnya sebesar 0,000 $(0,000233)$.

Net income (NI) dalam penelitian ini diukur dengan besarnya nilai laba/rugi bersih tahun berjalan dibagi market value of equity (MVE). Nilai rata-rata NI menunjukkan angka $-0,039$ yang berarti bahwa rata-rata perusahaan mengalami kerugian sebesar 0,039 dari total kapitalisasi pasar setiap awal tahun. Nilai deviasi standar sebesar 0,386 menunjukkan bahwa sebaran data cukup luas dengan rentang nilai NI tertinggi dan terendah memiliki kesenjangan yang cukup besar. Nilai NI tertinggi adalah sebesar 0,825. Hal ini menunjukkan bahwa perusahaan memiliki laba tertinggi selama periode penelitian. Sedangkan nilai NI terendah adalah -1,976 yang berarti bahwa perusahaan mengalami kerugian terbesar selama periode penelitian sebesar 1,976 dari total kapitalisasi pasar awal tahun.

Selisih net income $(\Delta \mathrm{NI})$ diukur dengan menggunakan selisih nilai laba/rugi bersih tahun berjalan dengan laba/rugi bersih tahun sebelumnya pada periode yang sama dibagi dengan market value of equity (MVE). Nila rata-rata $\Delta$ NI sebesar $-0,118$, pasar pada awal tahun. Deviasi standar bernilai 0,520 , lebih besar dibandingkan nilai rata-ratanya. Hal ini menunjukkan bahwa sebaran data memiliki kesenjangan yang cukup besar antara nilai tertinggi dengan nilai terendah. Nilai tertinggi dari variabel $\Delta \mathrm{NI}$ adalah 1,074, sedangkan nilai terendah sebesar $-2,903$.

\section{Pengujian Hipotesis}

Berdasarkan uji signifikansi simultan F menunjukkan nilai signifikansi sebesar 0,001 lebih kecil dibandingkan tingkat kesalahan yang dapat ditolerir $(\alpha)$ sebesar 0,01 . Hal ini berarti bahwa seluruh variabel penelitian secara simultan berpengaruh terhadap variabel dependen, return (RET). Dalam uji koefisien determinasi nilai adjusted Rsquare menunjukkan angka 0,346 atau sebesar $34,6 \%$ variasi return dapat dijelaskan oleh model, sedangkan sisanya sebesar $65,4 \%$ return dijelaskan oleh variabel lain di luar model.

Tabel 3 menunjukkan bahwa variabel utama revaluasi aset tetap (RFA), leverage (LEV), net income (NI) dan selisih net income $(\Delta \mathrm{NI})$ memiliki koefisien positif, sedangkan satu variabel utama lainnya, yaitu moderasi leverage (RFA_LEV) memiliki koefisien negatif. Koefisien beta 
dari variabel revaluasi aset tetap (RFA) sebesar 0,080 dengan nilai signifikansi 0,453, tidak signifikan pada tingkat 0,01, 0,05 , maupun 0,1 . Hal ini menunjukkan bahwa variabel revaluasi aset tetap tidak memiliki pengaruh terhadap return. Variabel leverage (LEV) memiliki koefisien beta sebesar $-0,021$ dengan signifikansi 0,641, tidak signifikan pada tingkat yang dapat ditolerir. Nilai ini menunjukkan bahwa variabel leverage tidak memiliki pengaruh terhadap return. Variabel ketiga, moderasi leverage terhadap revaluasi aset tetap (RFA_LEV) memiliki pengaruh negatif dan signifikan terhadap return. Hal ini ditunjukkan dari besarnya nilai koefisien beta, yaitu sebesar $-0,071$ dengan nilai signifikansi 0,070, signifikan pada tingkat 0,1 . Dua variabel lain yaitu net income (NI) memiliki hubungan signifikan negatif yang ditunjukkan dengan nilai koefisien beta 0,697 dengan signifikansi 0,003, signifikan pada tingkat 0,01 . Variabel deltanet income $(\Delta \mathrm{NI})$ memiliki hubungan positif dan tidak signifikan. Hal ini ditunjukkan dengan koefisien beta sebesar 0,205 dengan signifikansi 0,252, tidak signifikan pada berbagai tingkat. Selanjutnya, penelitian ini menjelaskan interpretasi hasil uji statistik $\mathrm{t}$ untuk dua variabel utama, yaitu: revaluasi aset tetap (RFA) dan moderasi leverage (RFA_LEV) karena kedua variabel tersebut berkaitan langsung dengan hipotesis penelitian.

Tabel 3

Hasil Uji Statistik t

\begin{tabular}{lcc}
\hline Variabel & Koefiisien Beta & Nilai Signifikansi \\
\hline RFA & 0,080 & 0,453 \\
LEV & $-0,021$ & 0,642 \\
RFA_LEV & $-0,071$ & $0,070^{*}$ \\
NI & $-0,697$ & $0,003 * * *$ \\
$\Delta$ NI & 0,205 & 0,252 \\
\hline
\end{tabular}

***Signifikan pada tingkat 0,01

*Signifikan pada tingkat 0,10

Sumber: Data sekunder yang diolah, 2017

Hipotesis pertama dalam penelitian ini adalah revaluasi aset tetap memiliki relevansi nilai. Unstandardized coefficients (Beta) digunakan untuk menunjukkan pengaruh positif atau negatif, sedangkan relevansi nilai ditunjukkan dengan adanya hubungan yang signifikan dari variabel revaluasi aset tetap (RFA) terhadap 
variabel dependen, return (RET). Nilai koefisien beta variabel revaluasi aset tetap dalam tabel 3 menunjukkan nilai sebesar 0,080 dengan signifikansi sebesar 0,453. Nilai ini menunjukkan bahwa variabel revaluasi aset tetap tidak memiliki pengaruh terhadap return pada berbagai tingkat signifikansi yang dapat ditolerir.

Hipotesis kedua, leverage memoderasi relevansi nilai revaluasi aset tetap (RFA_LEV). Moderasi leverage ditunjukkan dengan adanya hubungan signifikan antara variabel RFA_LEV dengan variabel dependen, return (RET). Hasil uji statistik $\mathrm{t}$ pada tabel 3 menunjukkan nilai koefisien beta variabel moderasi leverage sebesar -0,071 dengan nilai signifikansi 0,070 . Hal ini menunjukkan bahwa moderasi leverage memiliki pengaruh negatif dan signifikan pada tingkat signifikansi $(\alpha) \quad 0,10$. Berdasarkan uraian tersebut, variabel moderasi leverage (RFA_LEV) memiliki pengaruh yang negatif dan signifikan terhadap return (RET). Hal ini berarti bahwa adanya moderasi leverage akan menimbulkan reaksi negatif pada revaluasi yang dilakukan oleh perusahaan.

\section{Diskusi}

Hasil pengujian atas variabel revaluasi aset tetap terhadap return tidak memberikan pengaruh yang signifikan. Hal ini menunjukkan bahwa revaluasi aset tetap yang dilakukan perusahaan tidak memiliki pengaruh terhadap perubahan return saham. Investor tidak akan merespons sinyal perusahaan mengenai prospek masa depan maupun kondisi perusahaan yang sesungguhnya. Dengan demikian, penelitian ini membuktikan bahwa revaluasi aset tetap tidak memiliki relevansi nilai.

Hasil penelitian ini sejalan dengan penelitian yang dilakukan oleh Easton et al. (1993) yang menemukan lemahnya pengaruh revaluasi aset tetap terhadap return saham. Easton menganggap bahwa perusahaan mungkin salah dalam melakukan penilaian kembali (penentuan harga pasar), sehingga tingkat pengembalian dalam periode fiskal tidak mampu menangkap dampak kenaikan revaluasi. Oleh karena itu, selisih revaluasi belum tentu memiliki explanatorypower (kekuatan penjelas) terhadap return (Easton, et al., 1993).

Hipotesis pertama ditolak karena terdapat ketimpangan antara nilai minimum dan nilai maksimum antara satu perusahaan dengan yang lainnya, selain itu jumlah pengamatan yang kecil juga dapat menjadi salah satu penyebab ditolaknya hipotesis tersebut. Nilai standar deviasi yang lebih besar dibandingkan nilai rata-rata 
mengindikasikan bahwa data bersifat fluktuatif. Informasi tersebut dianggap tidak dapat dijadikan perhitungan mengenai pengambilan keputusan investor dalam merespons revaluasi yang dilakukan perusahaan. Dengan kata lain, revaluasi aset tetap tidak memiliki relevansi nilai.

Hasil pengujian hipotesis menunjukkan bahwa variabel moderasi leverage (RFA_LEV) memiliki pengaruh negatif dan signifikan terhadap return. Jumlah pengamatan yang kecil dapat menjadi salah satu penyebab diterimanya hipotesis tersebut dalam tingkat signifikansi 0,10. Hal ini berarti bahwa ketika moderasi leverage naik, maka return akan menurun. Hubungan ini mencerminkan bahwa ketika revaluasi aset tetap dilakukan oleh perusahaan yang memiliki leverage yang cukup tinggi, investor justru akan bereaksi secara negatif. Investor memandang bahwa perusahaan melakukan revaluasi untuk memperoleh rasio keuangan yang baik dengan tujuan menghindari pelanggaran perjanjian utang. Dengan demikian, manajer mungkin memiliki motif oportunistik dalam melakukan revaluasi aset tetap. Hasil penelitian ini sejalan dengan penelitian yang dilakukan oleh Brown et al. (1992) dan Courtenay dan Cahan (2004).

Perusahaan bertujuan untuk menghindari pelanggaran perjanjian utang, misalnya, penghindaran pembayaran denda dan biaya renegosiasi kontrak dengan melakukan revaluasi aset tetap (Brown et al., 1992). Revaluasi aset ini dilakukan untuk memperoleh rasio keuangan yang baik. Ketika total ekuitas bertambah akibat dari peningkatan saldo revaluasi, rasio utang terhadap ekuitas akan semakin baik. Hal yang sama juga terjadi, apabila nilai aset bertambah akibat revaluasi, maka rasio utang terhadap aset juga akan semakin baik karena nilai pembaginya menjadi semakin besar. Berdasarkan hubungan negatif pada moderasi leverage, hal ini menunjukkan bahwa perusahaan dengan rasio leverage yang rendah berpotensi mendapatkan return yang lebih tinggi. Dengan return yang lebih tinggi, memungkinkan perusahaan mampu membayar beban tetap perusahaan (misalnya, bunga).

Sejalan dengan teori kontrak utang yang dikemukakan oleh Brown et al. (1992), revaluasi aset berwujud dapat memperbaiki rasio utang terhadap aset karena nilai aset berwujud meningkat. Hal ini dapat mengurangi hambatan dalam perjanjian utang. Brown et al. (1992) menyatakan bahwa batasan formal pada rasio leverage yang ditentukan dalam syarat perjanjian utang akan meningkatkan kemungkinan manajer untuk melakukan revaluasi. Atas dasar inilah perusahaan berusaha memperbaiki rasio leverage melalui revaluasi aset untuk menghindari terjadinya pelanggaran perjanjian utang. 
Dengan demikian, manajer memiliki motif oportunistik dalam melakukan revaluasi aset tetap.

\section{KESIMPULAN， IMPLIKASI， DAN KETERBATASAN}

Penelitian ini bertujuan untuk menguji apakah revaluasi aset tetap memiliki relevansi nilai dan apakah leverage memoderasi relevansi nilai tersebut. Moderasi leverage ini dimaksudkan untuk mengetahui motif manajer dalam melakukan revaluasi aset tetap. Data yang digunakan dalam penelitian ini berasal dari perusahaan non keuangan yang terdaftar di BEI pada tahun 2011-2015. Dari berbagai kriteria yang telah ditetapkan, terdapat 36 perusahaan non keuangan, yang memenuhi kriteria pengambilan sampel. Total data yang diuji dalam penelitian ini sebanyak 54 pengamatan.

Dari hasil analisis data dan pembahasan pada bab sebelumnya dapat disimpulkan bahwa hasil pengujian hipotesis pertama adalah ditolak, dan hipotesis kedua adalah diterima. Pertama, revaluasi aset tetap tidak memiliki relevansi nilai. Hal ini menunjukkan bahwa investor tidak akan bereaksi atau tidak merespons sinyal dari perusahaan. Kedua, leverage memoderasi hubungan revaluasi aset tetap dengan return saham. Ketika revaluasi dilakukan oleh perusahaan dengan leverage yang tinggi, maka investor akan bereaksi secara negatif. Hal ini menunjukkan bahwa manajer memiliki motif oportunistik dalam melakukan revaluasi aset tetap. Sesuai dengan Teori Kontrak Utang yang dikemukakan oleh Brown et al. (1992) bahwa perusahaan bertujuan untuk menghindari pelanggaran perjanjian utang dengan cara memperbaiki rasio leverage melalui revaluasi aset tetap.

Penelitian ini telah membuktikan bahwa keputusan untuk merevaluasi aset tetap tidak memiliki dampak terhadap perubahan return saham. Namun, ketika revaluasi tersebut dilakukan oleh perusahaan yang memiliki tingkat utang tinggi, investor memandang bahwa manajer memiliki motif oportunistik untuk menghindari pembayaran denda atas pelanggaran perjanjian utang (Brown et al., 1992).

Keterbatasan-keterbatasan yang muncul dalam penelitian ini, yaitu, pertama, jumlah sampel yang sangat kecil, sehingga hasil dari penelitian ini tidak dapat digeneralisasikan. Kedua, penelitian ini hanya berfokus pada revaluasi aset tetap, sedangkan perusahaan dapat melakukan revaluasi aset tidak lancar lainnya. Ketiga, penggunaan model return menunjukkan hasil yang berbeda degan 
penelitian sebelumnya. Atas dasar keterbatasan-keterbatasan tersebut, maka untuk penelitian selanjutnya dapat melakukan perluasan objek penelitian seperti perluasan sektor perusahaan dan menggunakan periode pengamatan yang lebih panjang. Penelitian selanjutnya juga dapat melakukan perluasan variabel penelitian, seperti menambahkan variabel revaluasi properti investasi, revaluasi aset keuangan, dan sebagainya, serta dapat menggunakan model harga untuk menilai ada tidaknya relevansi nilai. Hal ini dimaksudkan agar penelitian dapat memberikan gambar yang lebih komprehensif mengenai relevansi nilai revaluasi aset, serta dapat menyempurnakan penelitian ini.

\section{DAFTAR PUSTAKA}

Aboody, D., Barth, M. E., \& Kasznik, R. (1999). Revaluations of Fixed Assets and Future Firm Performance: Evidence from the UK. Journal of Accounting and Economics, 26(1-3), 149-178. https://doi.org/10.1016/S01654101(98)00040-8

Andison. (2015). Fixed Asset Revaluation: Market Reactions (No. 29). Simposium Nasional Akuntansi XVIII. Retrieved lib.ibs.ac.id/materi/SNA XVIII/makalah/029.pdf

Barth, M. E., \& Clinch, G. (1998). Revalued Financial, Tangible, and Intangible Assets: Associations with Share Prices and Non-Market-Based Value Estimates. Journal of
Accounting Research, 36(3), 199233. https://doi.org/10.2307/2491314

Beaver, W. H. (1968). The Information Content of Annual Content The Information Announcements Earnings. Journal of Accounting Research, 6, 67-92.

Brown, P., Izan, H. Y., \& Loh, A. L. (1992). Fixed Asset Revaluations and Managerial Incentives. Abacus, 28(1), 36-57. https://doi.org/10.1111/j.14676281.1992.tb00268.x

Cahan, S. F., Courtenay, S. M., Gronewoller, P. L., \& Upton, D. R. (2000). Discussion of Value Relevance of Mandated Comprehensive Income Disclosures. Journal of Business and Accounting, 27(9), 1303-1309.

Choi, T. H., Pae, J., Park, S., \& Song, Y. (2012). Asset Revaluations: Motives and Choice of Items to Revalue. AsiaPacific Journal of Accounting \& Economics, (March 2014), 1-28. https://doi.org/10.1080/16081625.201 2.719858

Courtenay, S. M., \& Cahan, S. F. (2004). The Impact of Debt on Market Reactions to the Revaluation of Noncurrent Assets. Pacific-Basin Finance Journal, 12, 219-243. https://doi.org/10.1016/S0927538X(03)00021-0

Easton, P. D., Eddey, P. H., \& Harris, T. S. (2011). An Investigation of Revaluations of Tangible Long-Lived Assets, 31(1993), 1-38.

Ghozali, I. (2011). Aplikasi Analisis Multivariate dengan Program IBM SPSS 19 (5th ed.). Semarang: Universitas Diponegoro.

Gu, Z. (2007). Across-sample 
Incomparability of $\mathrm{R} \quad 2 \quad \mathrm{~s}$ and Additional Evidence on Value Relevance Changes Over Time. Journal of Business Finance \& Accounting, 34(7 \& 8), 1073-1098. https://doi.org/10.1111/j.14685957.2007.02044.x

Horn, V., \& Wachowicz. (2007). PrinsipPrinsip Keuangan 2 (12th ed.). Retrieved from https://books.google.co.id/books?id= 6ILNYYk4vkC\&pg=PP3\&dq=van+horne + dan + wachowicz $+2007 \&$ hl $=$ ban\&sa $=X \&$ re dir_esc $=\mathrm{y} \# \mathrm{v}=$ onepage $\& \mathrm{q}=\mathrm{van}$ horne dan wachowicz $2007 \& \mathrm{f}=$ false

IAI. (2011). Pernyataan Standar Akuntansi Keuangan 16. Retrieved September 20, 2016, from https://staff.blog.ui.ac.id/martani/files /2011/04/ED-PSAK-16.pdf

IAIglobal. (2015). IAI Dukung Kebijakan Pemerintah Terkait Revaluasi. Retrieved September 20, 2016, from http://iaiglobal.or.id/v03/beritakegiatan/detailberita-864-market

Kemenkopmk. (2015). Pemerintah Keluarkan Paket Kebijakan Ekonomi Jilid 5. Retrieved September 20, 2016, from http://www.kemenkopmk.go.id/artike 1/pemerintah-keluarkan-paketkebijakan-ekonomi-jilid-5

Maruli. (2014). Pengertian, Konsep Leverage Menurut Para Ahli. Retrieved March 1, 2017, from http://xerma.blogspot.co.id/2014/04/p engertian-konsep-leverage-menurutahli.html

Missonier-Piera, F. (2007). Motives for Fixed-Asset Revaluation: An Empirical Analysis with Swiss Data. International Journal of Accounting,
$42(2)$,

186-205. https://doi.org/10.1016/j.intacc.2007. 04.006

Sawir, A. (2004). Kebijakan Pendanaan dan Restrukturisasi Perusahaan. Retrieved September 23, 2016, from https://books.google.co.id/books?id= y-cTv8LGoAC\&pg=PR3\&dq $=$ sawir $+2004+\mathrm{Keb}$ ijakan+Pendanaan+dan+Restrukturisa si+Perusahaan. $\& h l=$ ban $\& s a=X \&$ redir _esc $=\mathrm{y} \# \mathrm{v}=$ onepage \&q=sawir 2004 Kebijakan Pendanaan dan Restrukturisasi Perusahaan.\&f=false

Simbolon, H. A. (2010). Value Relevance. Retrieved October 28, 2016, from https://akuntansiterapan.com/2010/06 /16/value-relevance/\#more-71

Whittred, G., \& Chan, Y. K. (1992). Asset Revaluations and the Mitigation of Underinvestment. Abacus, 28(1), 5874. https://doi.org/10.1111/j.14676281.1992.tb00269.x 